\title{
Is Mosul Dam the Most Dangerous Dam in the World? Review of Previous Work and Possible Solutions
}

\author{
Nadhir Al-Ansari' ${ }^{1}$, Nasrat Adamo, Varoujan Sissakian², Sven Knutsson'1, Jan Laue ${ }^{1}$ \\ ${ }^{1}$ Lulea University of Technology, Lulea, Sweden \\ ${ }^{2}$ University of Kurdistan, Erbil, Iraq \\ Email: nadhir.alansari@ltu.se, nasrat.adamo@yahoo.com, varoujan49@yahoo.com, Sven.Knutsson@ltu.se, jan.laue@ltu.se
}

How to cite this paper: Al-Ansari, N., Adamo, N., Sissakian, V., Knutsson, S. and Laue, J. (2017) Is Mosul Dam the Most Dangerous Dam in the World? Review of Previous Work and Possible Solutions. Engineering, 9, 801-823.

https://doi.org/10.4236/eng.2017.910048

Received: August 31, 2017

Accepted: September 27, 2017

Published: September 30, 2017

Copyright (c) 2017 by authors and Scientific Research Publishing Inc. This work is licensed under the Creative Commons Attribution International License (CC BY 4.0).

http://creativecommons.org/licenses/by/4.0/

\begin{abstract}
Mosul Dam is an earth fill dam located on the Tigris River in North Western part of Iraq. It is $113 \mathrm{~m}$ in height, $3.4 \mathrm{~km}$ in length, $10 \mathrm{~m}$ wide in its crest and has a storage capacity of 11.11 billion cubic meters. It is, constructed on bedrocks which consist of gypsum beds alternated with marl and limestone, in cyclic nature. The thickness of the gypsum beds attains $18 \mathrm{~m}$; they are intensely karstified even in foundation rocks. This has created number of problems during construction, impounding and operation of the dam. Construction work in Mosul Dam started on January $25^{\text {th }}, 1981$ and started operating on $24^{\text {th }}$ July, 1986. After impounding in 1986, seepage locations were recognized. The cause of seepage is mainly due to: 1 ) The karsts prevailing in the dam site and in the reservoir area. 2) The existence of gypsum/anhydrite rock formations in the dam foundation alternating with soft marl layers and weathered and cavernous limestone beddings. 3) The presence of an extensive ground water aquifer called Wadi Malleh aquifer, which affects considerably the ground water regime in the right bank. The dissolution intensity of the gypsum/anhydrite ranged from 42 to 80 t/day which was followed by a noticeable increase in the permeability and leakages through the foundation. Inspection of the dam situation in 2014 and 2015 indicates that the dam is in a state of extreme unprecedentedly high relative risk. In this work, possible solutions to the problem are to be discussed. It is believed that grouting operations will elongate the span life of the dam but do not solve the problem. Building another dam downstream Mosul Dam will be the best protective measures due to the possible failure of Mosul Dam, to secure the safety of the downstream area and its' population.
\end{abstract}

\section{Keywords}

Mosul Dam, Tigris River, Dam Failure, Karstification, Flooding, Iraq 


\section{Introduction}

Mosul Dam is located on the Tigris River in North Western part of Iraq; approximately $60 \mathrm{~km}$ northwest of Mosul city [1] (Figure 1). Mosul Dam is one of the most important strategic projects in Iraq for management of its water resources. Construction of Mosul Dam began on January $25^{\text {th }}, 1981$ and started operating on July $7^{\text {th }}, 1986$. The dam is a multipurpose project to provide water for many irrigation projects located in the north and south of Iraq, flood control and hydropower generation. The dam is $113 \mathrm{~m}$ high and $3650 \mathrm{~m}$ long including the spillway. The top width is $10 \mathrm{~m}$ at the $341 \mathrm{~m}$ (a.s.l.) crest level. The dam is an earth fill type with a clay core. The upstream side is faced with rock [1]. The dam was designed to impound $11.11 \mathrm{~km}^{3}$ of water at the normal operation level, including 8.16 and $2.95 \mathrm{~km}^{3}$ of live and dead storage respectively (Figure 2).

The dam has a concrete spillway located on the left abutment. The weir crest elevation of the spillway is $317.5 \mathrm{~m}$ (a.s.l.) and its length is $680 \mathrm{~m}$. The spillway has five radial gates measuring $13.5 \mathrm{~m} \times 13.5 \mathrm{~m}$ giving a discharge of $12,600 \mathrm{~m}^{3}$

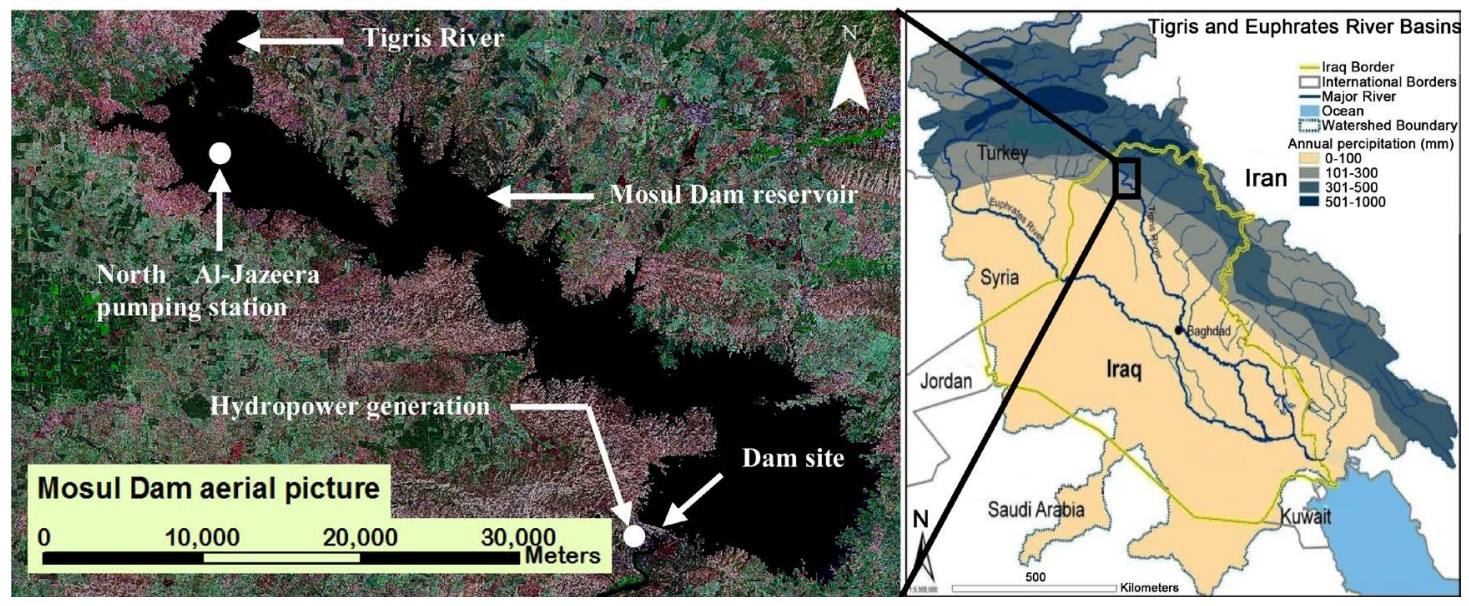

Figure 1. Location of Mosul Dam with main facilities.

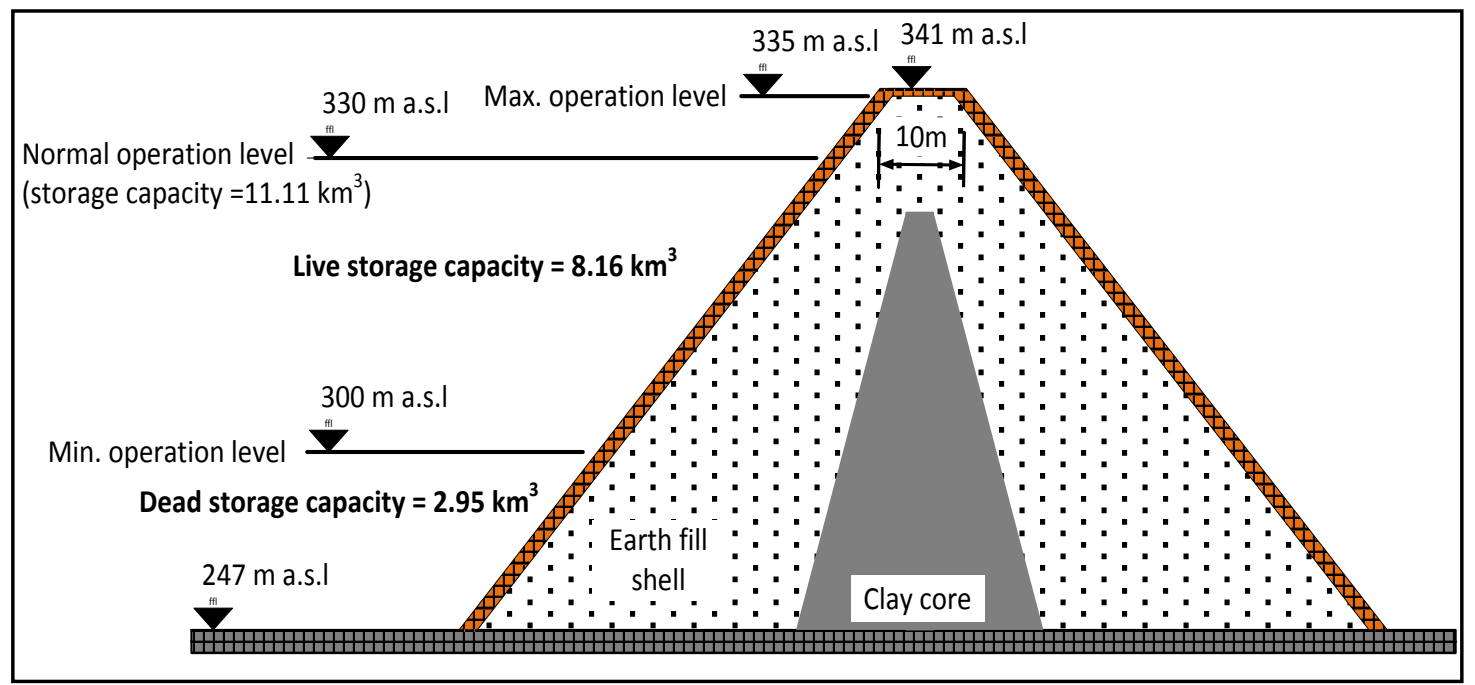

Figure 2. Schematic diagram of Mosul Dam cross section. 
sec-1 at the maximum reservoir level of $338 \mathrm{~m}$ (a.s.l.) [1]. The total cost of Mosul Dam was estimated at 2.6 billion US\$ at the prices level of 1980 s.

After impounding in 1986, seepage locations were recognized. The seepage due to the dissolution of gypsum and anhydrite beds raised a big concern for the safety of the dam and its possible failure. This problem was kept in a small closed circle within the Iraqi Ministry of Water Resources (previously Ministry of Irrigation) till the US Army Corps of Engineers conducted a study on Mosul Dam for the period June, 2004 to July, 2006 and highlighted the possibility of the dam failure. News media had highlighted this concern in 2014 when ISIS occupied the dam site area. It was reported that about 500,000 would lose their lives in case of Mosul Dam failure. Loses of property and destruction of the infrastructure of the main cities downstream the dam will be enormous, and the flood wave will reach the capital city Baghdad. In this research, the main geological and engineering problems will be highlighted, and possible solution will be recommended.

\section{Geology of the Area}

In the vicinity of Mosul Dam, the exposed formation is Lower Fars (Fatha). It is composed of alternating beds of limestone, marl and gypsum [2]. The dam abutments are located on the Upper Member of the Fatha Formation (Middle Miocene) (Figure 3). The Upper Member, as the Lower Member of the Fatha Formation consists of cyclic sediments, marls, clay stone, limestone and gypsum; however, in the uppermost part the clay stone ratio increases as compared with the lower part. These inhomogeneous rocks; in their mechanical behavior, will certainly behave differently when are loaded. The gypsum and limestone beds are usually karstified, but the Karstification is less in the Upper Member as compared to Lower Member of the Fatha Formation [3] [4]. This is attributed to the presence of more clastics in the Upper Member than that of the Lower Member of the Fatha Formation, besides that gypsum and limestone beds become thin in the uppermost parts of the formation.

Due to the complexity of the geology of the area, several investigations were carried out (e.g. [5]-[19]). Al-Ansari et al. [2] reported that there were two faults within the dam site area. The first is of rotational type striking NW-SE offsetting the northern corner of Butmah East structure. The other fault is trending $\mathrm{N}$ NE-S SW along the right bank of the River Tigris. This fault is not clear on the surface and it was detected using Landsat images. This is due to the fact that the fault is deep seated and it might be partly controlling the Tigris River course from the dam site to Aski Mosul. Wakeley et al. [20] collected all the borehole data and constructed a model to show the complex geology at the dam site (Figure 3).

No tectonic activity is reported from the dam site and near surroundings [21]. Furthermore, the present small faults, as discovered at the dam site during execution of detailed geological mapping by Iraq Geological Survey has no signifi- 


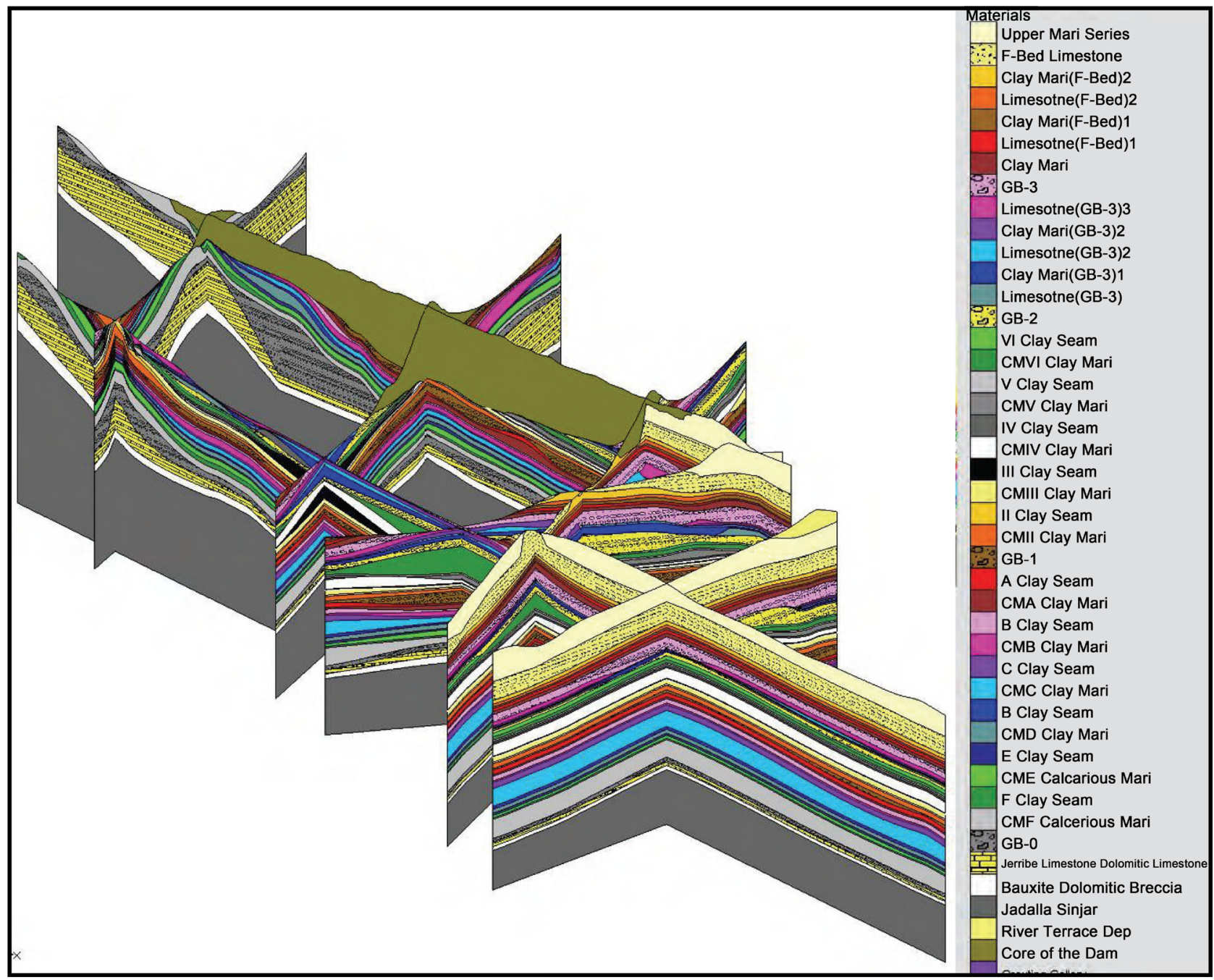

Figure 3. Intersecting cross sections from intermediate version of ERDC geologic conceptual model, showing complex stratigraphy and partial resolution of discrepancies in stratigraphy at intersections of the geologic panels from generated boreholes [20].

cant importance and/ or causes any hazard for the dam [5]-[19]. Therefore, the area of the dam site almost doesn't suffer from active tectonic disturbances; this is also confirmed by Kelly et al. [22], when they stated that the dam body does not suffer from any problem.

\section{The Problem}

The geology created a number of problems during construction, impounding and operation of the reservoir. After impounding in 1986, seepage locations were recognized. The cause of seepage is mainly due to geological problems that can affect the safety of the dam. These problems are:

- The karsts prevailing at the dam site and in the reservoir area.

- The existence of gypsum/anhydrite rock formations in the dam foundation alternating with soft marl layers and weathered and cavernous limestone beddings.

- The presence of an extensive ground water aquifer called Wadi Malleh aqui- 
fer, which affects considerably the ground water regime in the right bank.

The most significant geological hazard that influences Mosul Dam is the Karstification, especially in the foundation's rocks. The influence of the Karstification is also confirmed by [2] [4] [7] [23]-[28]. The karst development extends to a depth of $100 \mathrm{~m}$ below the foundation of the dam. The Karstification enhanced the extensive dissolution of gypsum and gypsum anhydrite rocks present above and below the limestone layers. These dynamics caused the collapsing of whole layers of clayey marls into the underneath cavities forming beds composed of brecciated gypsum particles and anhydride blocks embedded into a loose clayey matrix. Four such layers were discovered during the geological investigations (Figure 4).

The presence of surface cracking and groundwater fluctuation give rise to the development of sinkholes. One sinkhole on the left flank of the reservoir appeared suddenly overnight in February 2003 and developed rapidly with $15 \mathrm{~m}$ of settlement and a $15 \mathrm{~m}$ diameter depression (Figure 5). Other sinkholes appeared on the right side downstream the dam (Figure 6). The rate of settlements of these sinkholes was $0.25 \mathrm{~m}$ when they appeared in 1992 and then reduced to $50 \%$ in 1998. The maximum cumulative settlement was recorded to be $5 \mathrm{~m}$ in a sinkhole SD4. It is believed that the formation of these sinkholes is due to the dissolution of surface gypsum beds, which led to the formation of conduits under the surface. This took place due to the groundwater flow from Wadi Malleh aquifer toward the River Tigris, and the recharge of this aquifer increased tremendously when the reservoir was impounded. The conduit has developed in size due to the fluctuation of the water level in the pond downstream the main dam caused by the operation of the regulating dam. Once the size of these caves increased and became closer to the surface they collapsed after heavy rainfall. Recent bathymetric survey conducted in 2011 showed the presence of a large number of sinkholes within the reservoir area (Figure 7). This is a dangerous phenomenon, especially if they are connected to Wadi Malleh aquifer, then they can cause numerous problems for the safety of the dam.

In addition, springs also appeared downstream the dam located on the same line of the sinkholes. The flow from the spring reached $360 \mathrm{l} / \mathrm{s}$ (Figure 8). The water had high concentration of sulphate indicating its origin from Wadi Malleh aquifer [30]. It should be mentioned, however, the amount of seepage flow from the Wadi Malleh aquifer was very high in the pumping storage scheme and the tailrace tunnel and its intake structure. The excavation of the caverns was only possible after performing extensive grouting works all around these caverns. The importance of the Wadi Malih aquifer is not only due to the great difficulties it caused during the construction of the pump storage scheme; but also that it shapes the ground water flow regime in and around the right abutment of the dam in addition to the fact that it contributed to the formation of a series of sinkholes at the right bank downstream of the main dam. The high concentration of sulphate in the water of this aquifer clearly indicates the dissolution of 


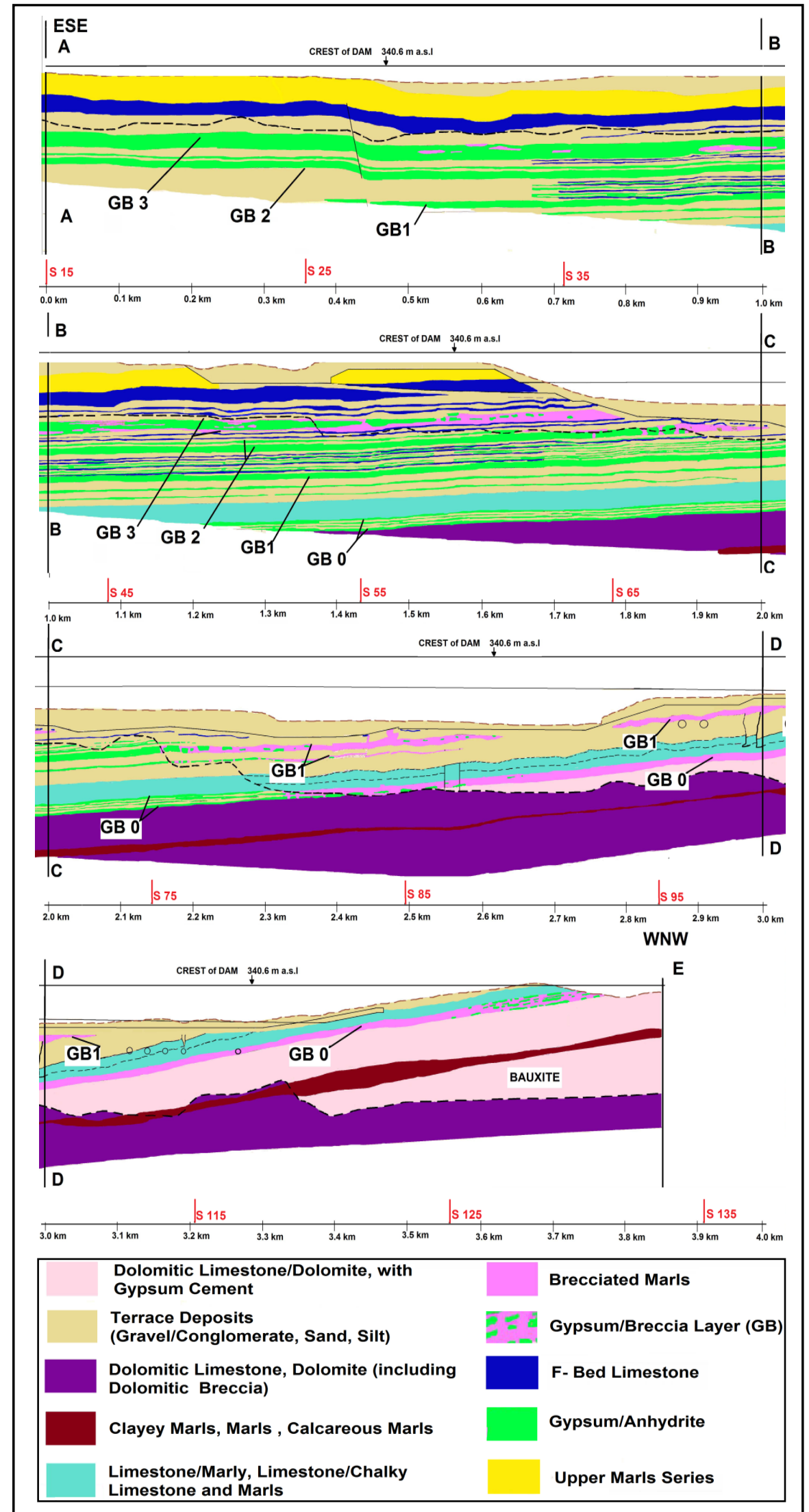

Figure 4. Geological Cross Section along the axis of the dam. 

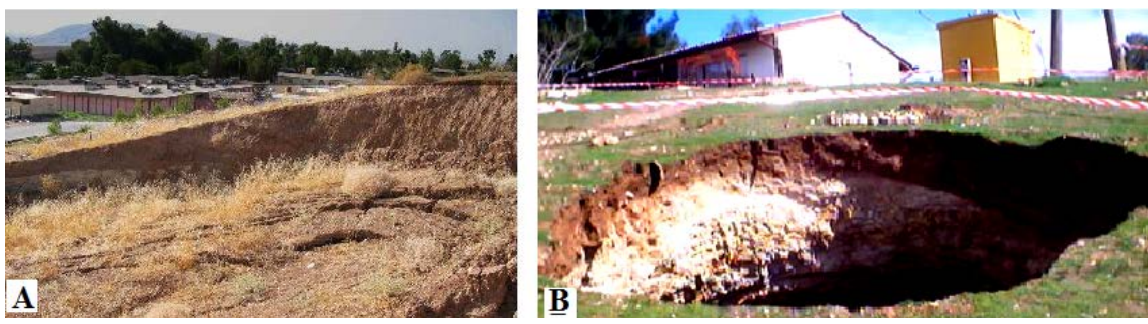

Figure 5. The left bank sinkhole (A) early stage (B) full development stage.

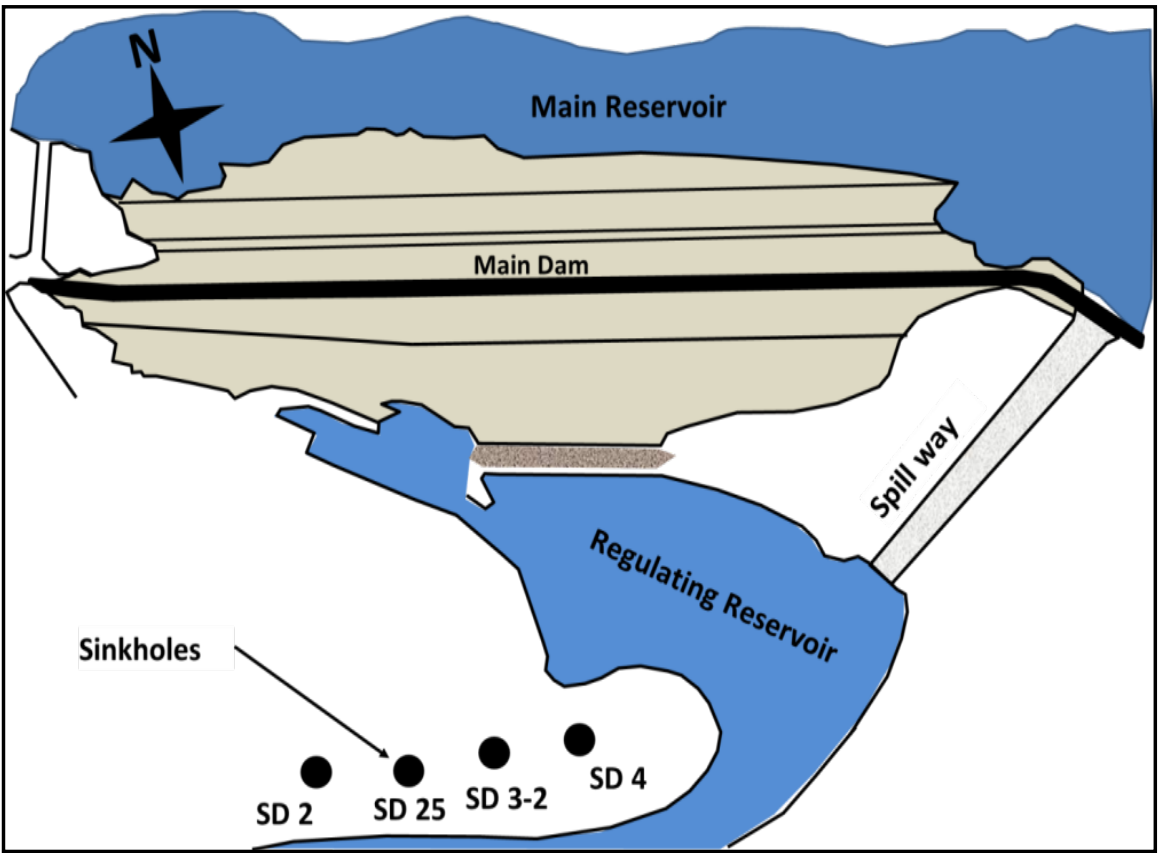

Figure 6. Sinkholes downstream Mosul Dam-Right Bank.

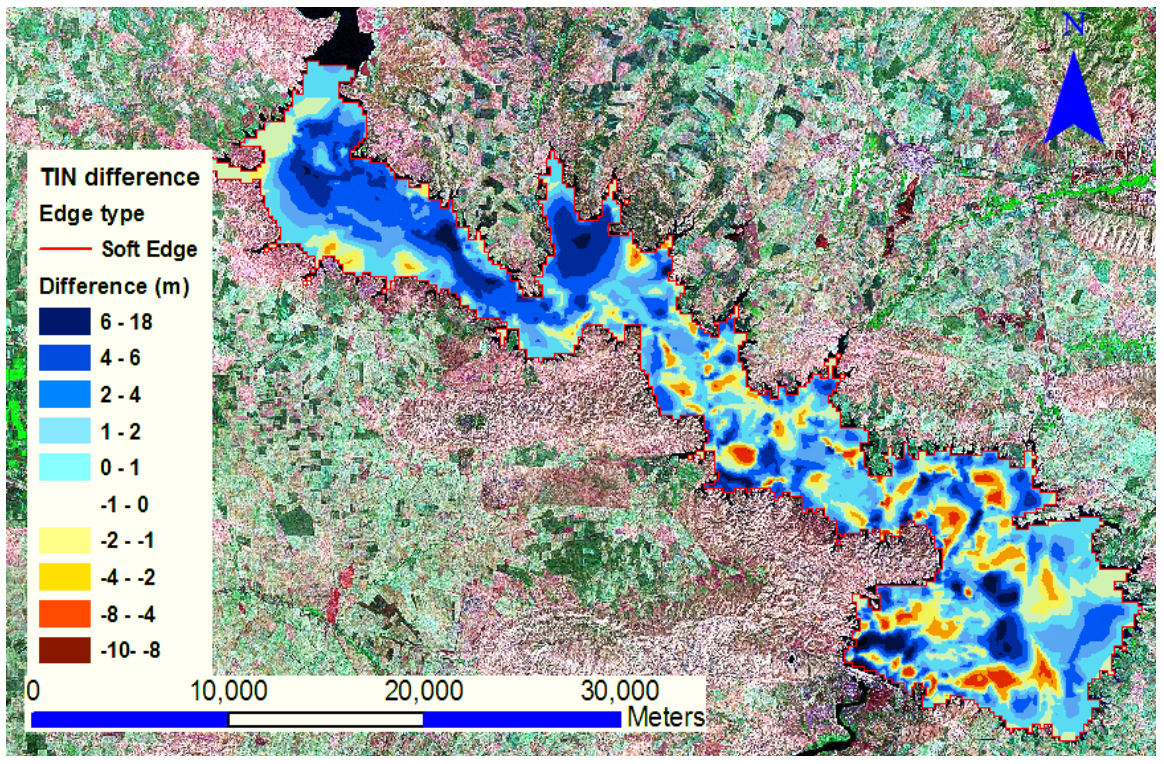

Figure 7. Holes noticed at the bed of Mosul reservoir [29]. 


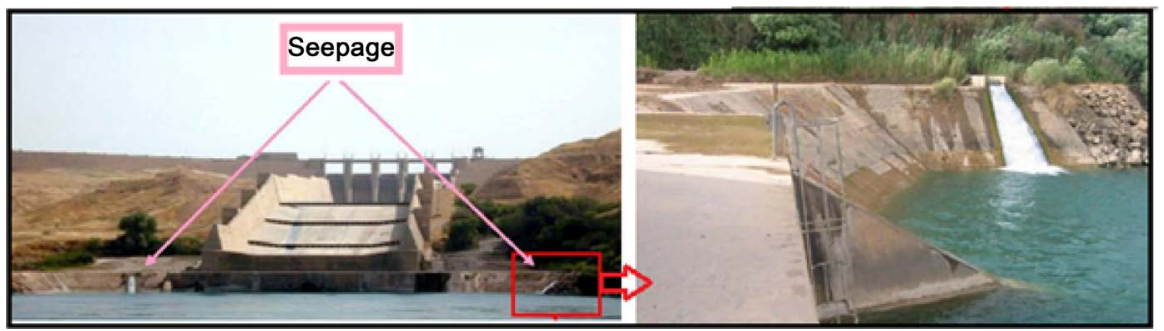

Figure 8. Example of seepage.

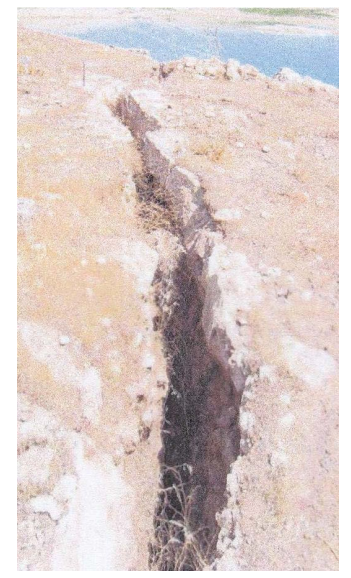

Figure 9. Fissure on the right slope side of the dam.

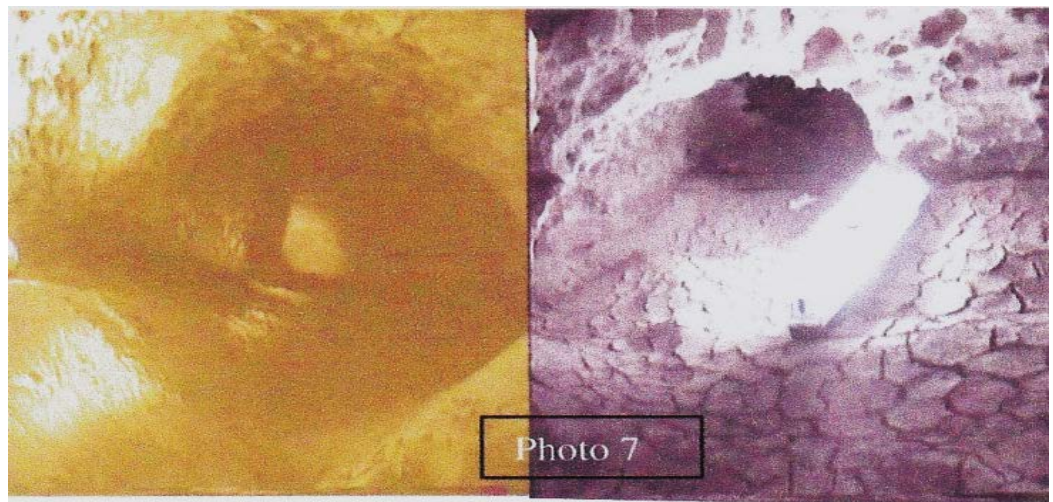

Figure 10. Large conduit found in March 2002 in the upper right rim of the reservoir.

gypsum from the dam site and its vicinity. In addition, the hydrostatic pressure of water within the reservoir is increasing the rates of dissolution. This process is in progress since the operation of the dam. This process also led to the appearance of other features like the fissure near $100 \mathrm{~m}$ from the right abutment of the dam which appeared in 2002 (Figure 9). Furthermore, the dissolution phenomena continued into later years. Figure 10 shows a large conduit which was discovered in March 2002 within a gypsum/anhydrite layer on the right side of the reservoir.

In view of the above, it can be clearly stated that there are a dynamic movement of groundwater within the dam site and its surrounding causing high rates of dissolution of gypsum associated with washing fine clay and carbonate small 
particles. This process is alarming where it can create large caves that can reach the surface of the ground leading to sudden collapse of the ground surface during the infiltration of surface water through the top cover of these caves. This was noticed in February 2003 (see Figure 5), October 2004 and July 2005. This phenomenon is old within the karstified rocks of the area and has been increasing in its rate due to the effect of the operation of the dam ([5]-[19]).

\section{Present Status of the Dam}

To evaluate the status of the geological conditions in the dam area, the Engineer's and Environmental center of research of the US Army Corps of Engineers [22] used the rock quality designation (RQD) [31] as an index for the description of rock mass fractured state. The comparison performed was on samples taken in 1989 and 2006. The results showed that RQD was 45\%-65\% and 0\% $20 \%$ for the two years respectively. The deterioration of the samples is due to the dissolution of gypsum (Figure 11).

In addition, the deep curtain grouting was also investigated. It was noticed that some parts were highly deteriorated and required grouting 4 or 5 times annually. It was also noticed that the dissolution front had progressed $350 \mathrm{~m}$ toward the east, i.e. an average of about $17 \mathrm{~m} /$ year. The samples recovered from the grouting gallery showed that all the rocks were replaced by friable grout material.

Taking this information into consideration, the following points can be highlighted:

- The dissolution phenomenon is not recent in Mosul Dam area. The impounding of Mosul Dam reservoir increased the rate of dissolution of the rocks. This led to the sudden appearance of sinkholes in the area.

- The bedding plains under the foundation of the dam represent weak areas, which eased the water movement along these surfaces. The movement of water along these surfaces increased the dissolution of rocks vertically and horizontally. Furthermore, the supply of fresh unsaturated water from Mosul Dam reservoir tremendously increased this process.

- The dip of the beds on the eastern side of the dam does not exceed 6 degrees

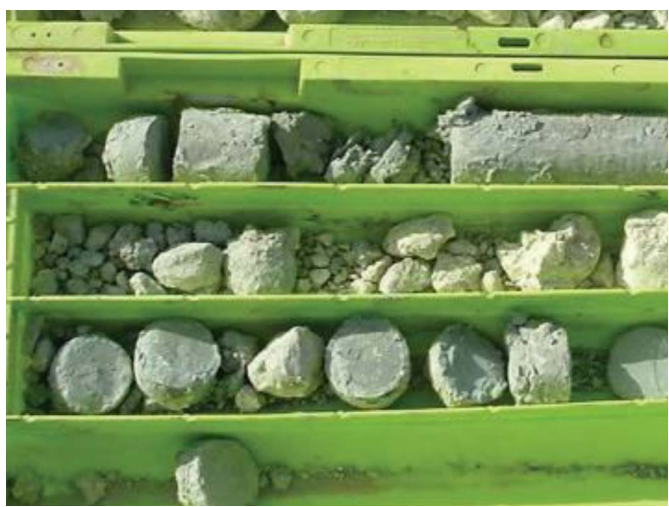

Figure 11. Samples recovered from well drilled near SD5 ([20]). 
in SE direction and this makes the groundwater to move along this direction. It was noticed that when the water level in the reservoir exceeds $318 \mathrm{~m}$. a. s. 1. the rate of dissolution increases. This is attributed to the rock types within the area. The beds on the far eastern part of the dam are horizontal, and that condition decreases the rate of dissolution. It should be also mentioned that the high dip of beds on the right side of Wadi Deer Al Malleh fold is so high, and this reduces the rates of dissolution there.

In view of the above, it is obvious that the situation of the dam is deteriorating with time. On the $8^{\text {th }}$ of August, 2014, the Islamic State of Iraq and Syria (ISIS) terrorists group seized control of the Mosul Dam, and it was seized back from the hands of ISIS on the $16^{\text {th }}$ of the same month. The end result of all this was the halting of the grouting operations which had continued for the past 30 years and had consumed more than 95000 tons of solid grouting materials, which were considered, even if temporary solution, the only one necessary to stabilize the foundation for some more time. In 2015, many United States agencies were led by the USACE to carry out measurements, surveys and observations to follow developments that might lead to the dam failure. The findings of the team were:

a) The concentration of sulfates in the seepage water increased indicating increased dissolution of gypsum.

b) Caverns and sinkholes were increasing under the dam. There were signs of increased formation of cavities under the dam. Dissolution of gypsum reached $10,000 \mathrm{~m}^{3}$ during the period August 2014 until beginning of 2016 due to discontinuation of grouting works.

c) Increased monolith movement in the grouting gallery and cracks' opening were noticed ([32] p. 12). The movements are believed to be caused by settlement and not resulting from onsite activity. Cumulative settlement in the grouting gallery from 1986 to the end of 2015 records showed a sharp increase in settlement in 2015 which indicates a worsening situation in the dam foundations ([32] p. 13). Satellite based information also indicated that there is local differential settlement in the body of Mosul Dam averaging from 5 to $10 \mathrm{~mm}$ /year [33] [34]. In December 2016, Milillo et al. [37] published their findings from space geodetic monitoring of Mosul Dam. They found that the rate of subsidence of Mosul Dam for the period 2004-2010 was $12.5 \mathrm{~mm} /$ year has increased to 15 $\mathrm{mm}$ /year after 2013 after re-grouting operations stopped (Figure 12). This subsidence is related to the dissolution of gypsum and the reservoir-induced pressure which is the main cause of an increase in the dissolution rates. They also added that any annual increase of water levels in the reservoir in the future could lead to an increase of water pressure in the dam foundation, which combined with the absence of re-grouting could speed up the dissolution of the dam substrate and promote its destabilization.

The plot of the data for Mosul Dam on the screening Portfolio Risk Analysis (SPRA) process for Dam Safety is shown in Figure 13. This plot considers loading frequency, an engineering rating to estimate a relative probability of failure, 

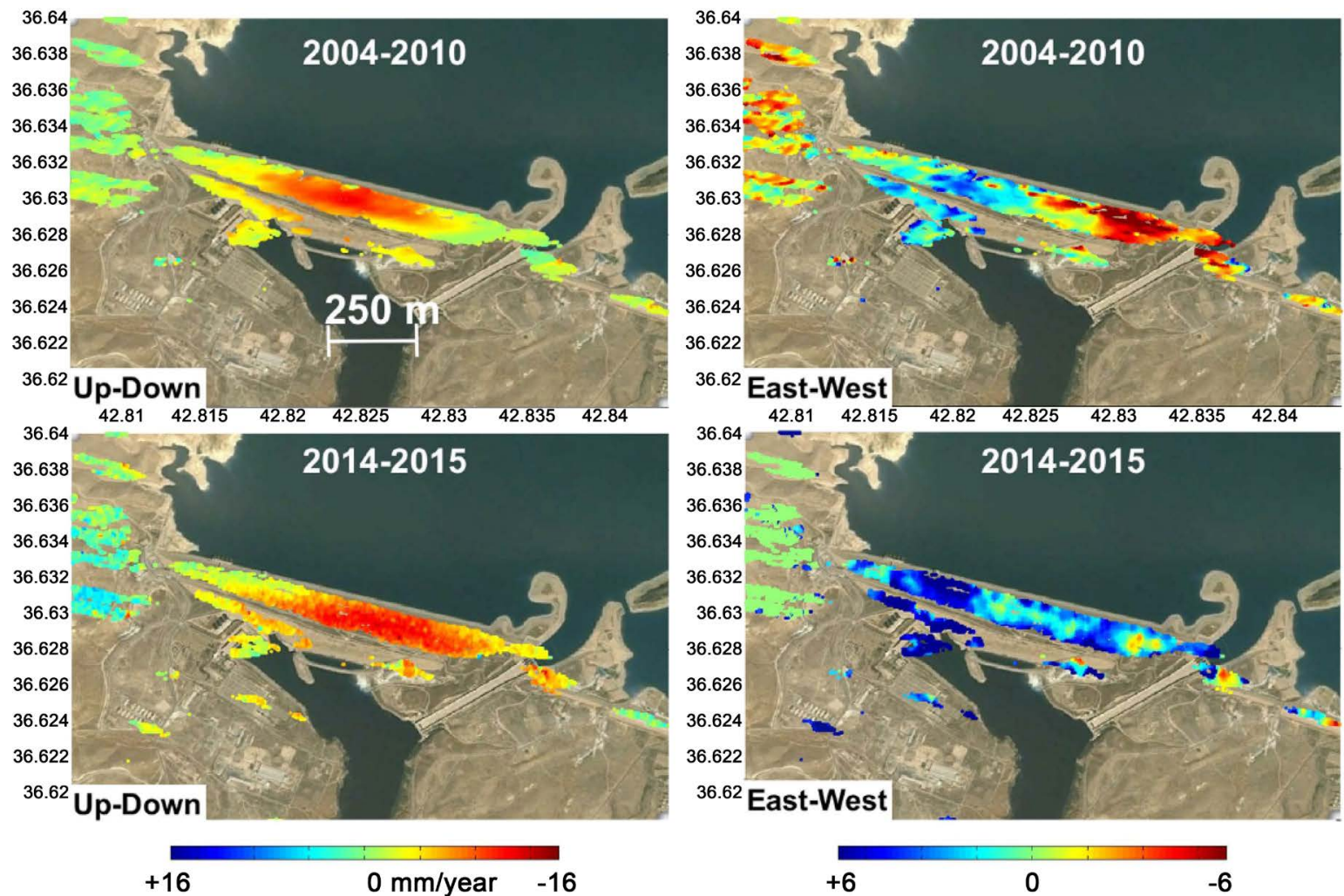

Figure 12. Up-down (left) and east-west (right) displacement at the Mosul dam, Iraq. Negative values indicate downward and westward motion respectively ([32]).

\section{Relative Risk}

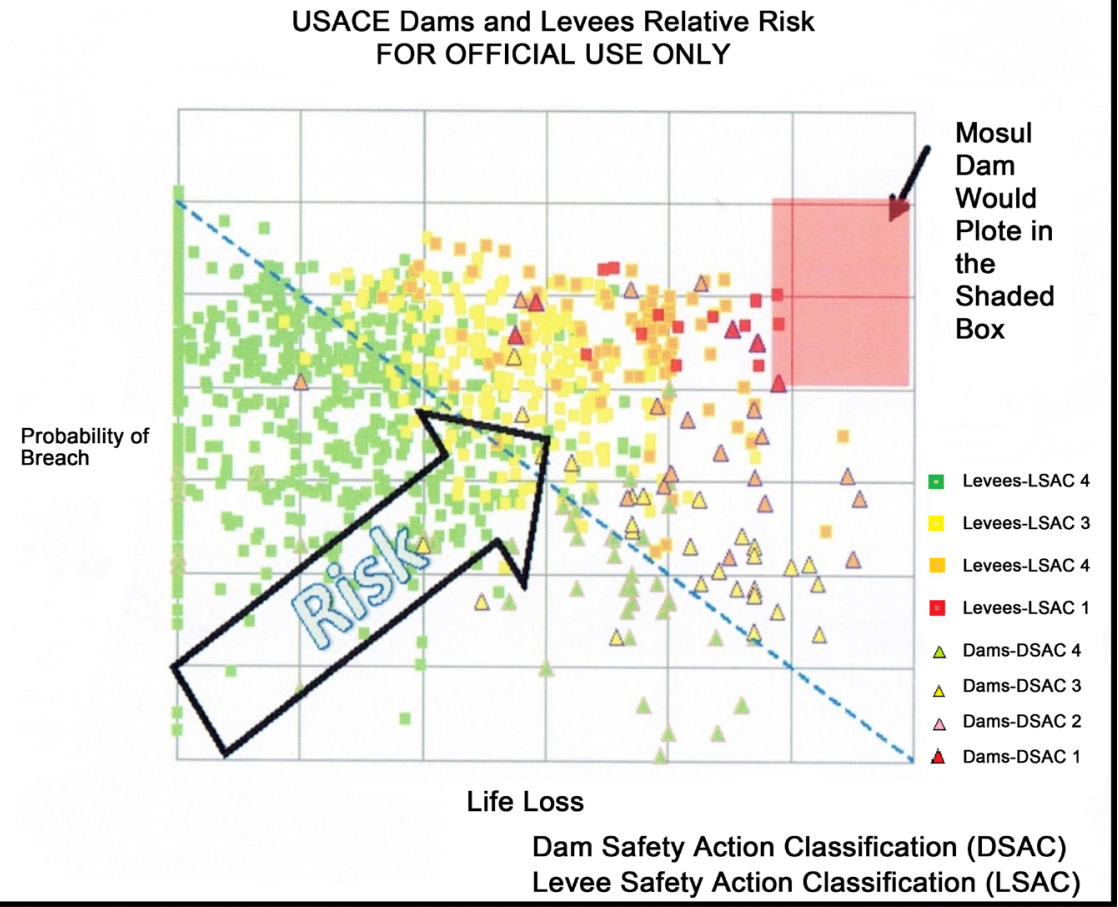

Figure 13. Screening Portfolio Risk Analysis (SPRA) for Mosul Dam [32]. 
and both human life loss and economic consequences of failure [35] [36]. This procedure shows that Mosul Dam is in a state of extreme relative risk (Figure 13). For more details, see ([5]-[19]).

\section{What Happens if the Dam Fails?}

In 1984, the Ministry of Irrigation commissioned the Swiss Consultants Consortium to carry out a potential dam break and flood wave study for Mosul Dam. The study was completed in three volumes report, which contained the possible causes of failure, full description of the mathematical model used, its calibration using known high flood recordings, and a complete flood routing of the wave in its way in the Tigris river valley down to (24) kilometers south of Baghdad [38] [39] [40] [41] [42]. Swiss consultant considered that if failure occurred; the most plausible cause would be piping in the foundation resulting in enlarged flows within the dam base which would progress to open a big gap in the dam. The model used in the simulation was (Flow in River Systems) best known as (FLORIS). The calibrating of the model showed that it fits best the recorded floods when manning (n) used was (0.030). For a flood wave of the size under consideration, the consultant adopted rightly a value of $(n)$ equals (0.033), and even checked what could happen if $(n)$ is $(0.050)$. For gap width, two values were considered; 700 meters and 200 meter respectively. The first value being the more plausible one as it is equal to the length of the dam section closing the river channel, while the second is in line with the Corps of Engineers practice of considering a gap width double the dam height. Six scenarios were run to get the hydrographs of the Flood wave for these scenarios. The results are shown in $\mathrm{Ta}$ ble 1 which is constructed from the tables and hydrographs given in the original study [38] [39] [40] [41] [42] and published in reference [19].

From Table 1, it can be seen that the initial maximum discharge of the wave may vary between $\left(551,000 \mathrm{~m}^{3} /\right.$ second to $\left(415,000 \mathrm{~m}^{3} /\right.$ second) according to the scenario under consideration. FLORIS was then used to route the wave all the way down to Baghdad for different possible water levels in the reservoir. Table 2 shows the peak discharges of the wave, its heights, and times of arrival at the different cities and towns along the river course.

This study was checked by Black \& Veatch in 2005. They outlined their conclusions in their report [27]. Their method was to decouple the derivation of the breach development hydrograph from routing the wave in the river channel. For the first part they used, the model (DAMBRK UK) upgraded to fit UK conditions by Binnie and Partners and the University of Bradford, and they indicated

Table 1. Scenarios of breach formation at Mosul Dam [39].

\begin{tabular}{ccccccc}
\hline Case & A & B & C & D & E & F \\
\hline Breach width of bottom $(\mathrm{m})$ & 700 & 700 & 700 & 700 & 200 & 200 \\
Breaching time (hours) & 4 & 4 & 5 & 5 & 2 & 2 \\
Roughness of the river channel Manning's (n) & 0.33 & 0.050 & 0.033 & 0.050 & 0.033 & 0.5 \\
\hline
\end{tabular}


Table 2. Reservoir out flow in $1000 \mathrm{~m}^{3} \cdot \mathrm{sec}^{-1}$ [41].

\begin{tabular}{ccccc}
\hline Hours/Case & A & B & C & D \\
\hline 0 & 1 & 1 & 1 & 1 \\
1 & 13 & 13 & 13 & 13 \\
1.5 & 80 & 80 & 80 & 80 \\
2.0 & 215 & 210 & 215 & 212 \\
2.5 & 372 & 356 & 335 & 325 \\
3.0 & 474 & 452 & 422 & 404 \\
3.5 & 535 & 499 & 480 & 453 \\
4.0 & 551 & 510 & 509 & 475 \\
4.5 & 538 & 469 & 497 & 460 \\
5.0 & 507 & 469 & 497 & 460 \\
6.0 & 405 & 382 & 435 & 405 \\
8.0 & 271 & 266 & 186 & 278 \\
10.0 & 186 & 192 & 195 & 198 \\
12.0 & 123 & 136 & 130 & 142 \\
18.0 & 37 & 47 & 39 & 49 \\
24.0 & 18 & 2 & 19 & 22 \\
\hline & & & & \\
\hline & 536 & & 49 \\
\hline
\end{tabular}

that the output could be fed to any of the two models (ISIS 2.2) developed by (HR Wallingford) and Halcrow (UK) or (MIKE 11) developed by the Danish Hydraulic Institute in order to carry out the wave flood routing. Both models had the capability of presenting the results in a graphical form and interfacing with GIS to provide details of impounded area. As a final judgment (Black \& Veatch) considered that both models did not add to the accuracy of the results in the Swiss Consultants using (FLORIS) and any additional output did not justify the additional work needed to apply any of these two models, so they accepted using (FLORES) for the flood wave routing. They considered finally that SC study was done in the best possible way and in a highly professional manner. Later, in (2009) and (2015) two more studies on the subject were done namely [43] [44]. In these studies, they used other models for the analysis but in using these models they assumed gap width and time of the gap breach without giving justification of the selected values. Their assumption of (n) value seemed also to be far from the real conditions. In addition to all this, no mention was given on how the calibration of their models, and its validation were done. These missing details result in many question marks and may shed doubt on the outcome of these studies.

A new study was performed by [45] from the Joint Research Center of the European Commission (JRC. They investigated the time evolution and characteristics of the flood wave and its impact on the population living along the Tigris River. The (HyFlux2) computer code was used, which had been developed at the 
center by [46]. This model was routinely used for tsunami and storm surge events but originally developed for dam break analysis problems.

Table 3 summaries the results of the studied scenarios for different reservoir levels and assuming the bottom of the breach at level (252), breach area equal (26\%) of the dam surface area, i.e. $40,560 \mathrm{~m}^{2}$ out of $155,000 \mathrm{~m}^{2}$. This table gives the peak height of the wave, time of arrival of the wave and time of arrival of its peak to five cities along the river. Accordingly, the wave will reach Mosul city after $1 \mathrm{hr} .40 \mathrm{~min}$. and Baghdad in 3.5 days. The maximum height will be about (26) meters and (8) meters in Mosul and Baghdad respectively. Figure 14 gives the wave peak height at five cities and its arrival time.

From LANDSAT 2014 Global population Database and the STRM91 and topography layers with resolution of $1 \mathrm{Km}^{2}$, the researchers arrived at the number of affected population at different depths of inundation. This was done by superimposing water depths of $(0.1 \mathrm{~m}, 0.5 \mathrm{~m}, 2.0 \mathrm{~m}, 5.0 \mathrm{~m}, 10 \mathrm{~m}$ and $>10 \mathrm{~m})$ on the (LANDSAT 2014) global population database to find the number of people between these levels. The studies arrived at very interesting statistics which is shown in Table 4. This table shows the total number of population and total areas affected for a scenario of reservoir water level of (330) which is the maximum reservoir design operation level.

From tables presented in this study Table 5 was also constructed. It gives the number of population affected at various reservoir water levels (RWL), for dif-

Table 3. Peak discharges in $1000 \mathrm{~m}^{3} \cdot \mathrm{sec}^{-1}$ [45].

\begin{tabular}{ccccc}
\hline Case & A & B & C & D \\
\hline km 00 main dam & 551 & 510 & 514 & 477 \\
Km 109.2 Regulating dam & 545 & 503 & 509 & 471 \\
Km 117.3 Eski Mosul & 481 & 429 & 456 & 409 \\
Km 169.2 Mosul city & 405 & 348 & 397 & 342 \\
Km 196.6 Haman Alil & 370 & 308 & 365 & 305 \\
\hline
\end{tabular}

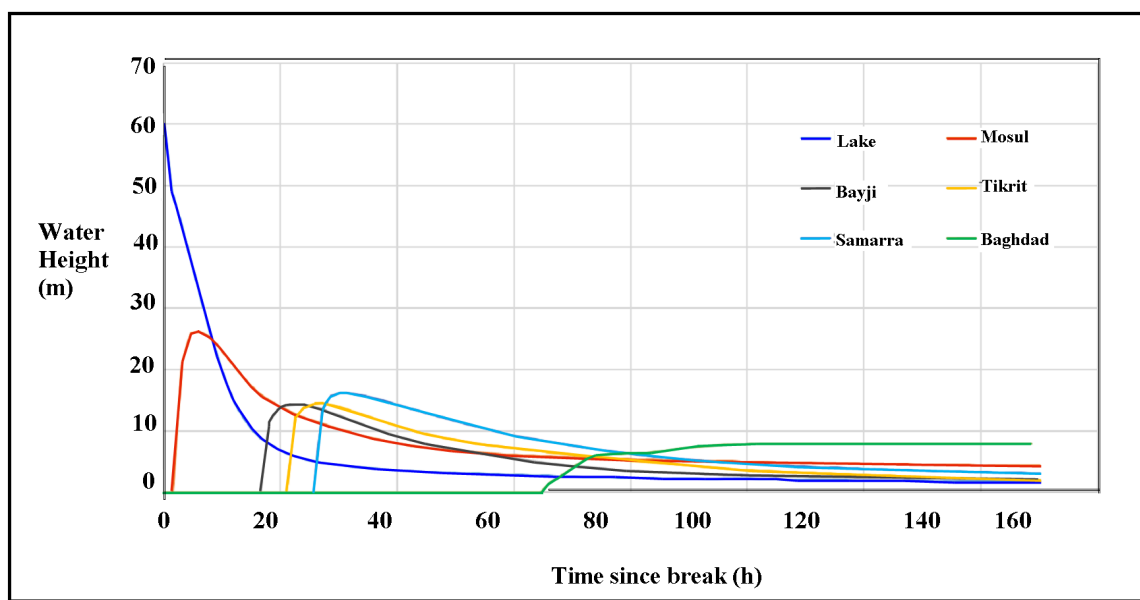

Figure 14. Mosul Dam Break: Height-Time graph [45]. 
Table 4. Number of People affected and areas inundated at various water depths of flood water for reservoir water level (330) [45].

\begin{tabular}{ccc}
\hline Inundation & Population & Area $\left(\mathrm{km}^{2}\right)$ \\
\hline $0.1-0.5 \mathrm{~m}$ & 948,000 & 637 \\
$0.5-2.0 \mathrm{~m}$ & $3,144,000$ & 2022 \\
$2-5 \mathrm{~m}$ & $1,626,000$ & 1150 \\
$5-10$ & 260,000 & 916 \\
$>10 \mathrm{~m}$ & 270,000 & 916 \\
Total & $\mathbf{6 , 2 4 8 , 0 0 0}$ & $\mathbf{7 2 0 2}$ \\
\hline
\end{tabular}

Table 5. Affected population for different periods and depths of inundation level in five major cities along river course ([45]).

\begin{tabular}{|c|c|c|c|c|c|c|c|}
\hline RWL & $\mathrm{T}$ & Inudation & Mosul & Bayji & Tikrit & Samara & Baghdad \\
\hline \multirow{5}{*}{330} & \multirow{5}{*}{6} & $0.1-0.5$ & 21,000 & 0 & 0 & 0 & 746,000 \\
\hline & & $0.5-2.0$ & 55,000 & 300 & 100 & 3000 & $2,949,000$ \\
\hline & & $2-5$ & 41,000 & 400 & 2500 & 100 & $1,134,000$ \\
\hline & & $5-10$ & 60,000 & 17,000 & 14,000 & 5500 & 26000 \\
\hline & & $>10$ & 183,000 & 2000 & 4000 & 3500 & 0 \\
\hline \multirow{5}{*}{319} & \multirow{5}{*}{6} & $0.1-0.5$ & 27,000 & 0 & 0 & 0 & 803,000 \\
\hline & & $0.5-2.0$ & 12,000 & 500 & 0 & 0 & $1,756,000$ \\
\hline & & $2-5$ & 510,000 & 15,000 & 3500 & 1000 & 750,000 \\
\hline & & $5-10$ & 66,000 & 4500 & 14,000 & 10000 & 78,000 \\
\hline & & $>10$ & 125,000 & 0 & 500 & 1000 & 0 \\
\hline \multirow{5}{*}{300} & \multirow{5}{*}{12} & $0.1-0.5$ & 14,000 & 500 & 500 & 1000 & 382,000 \\
\hline & & $0.5-2.0 \mathrm{~m}$ & 15,000 & 9500 & 7000 & 7000 & 850,000 \\
\hline & & $2-5$ & 86,000 & 3500 & 8000 & 3000 & 229,000 \\
\hline & & $5-10$ & 54,000 & 0 & 500 & 500 & 60,000 \\
\hline & & $>10$ & 4000 & 0 & 0 & 0 & 0 \\
\hline
\end{tabular}

ferent periods ( $\mathrm{T}$ ) and at different depths of inundation at the five biggest cities along river course shown. The scenarios of failure are:

- Reservoir water level $=330$ which is the maximum design operation water level. - Reservoir water level $=319$ which is the maximum operation water level adopted in (2006).

- Reservoir water level $=300$ which is the dead storage water level as per design.

From all these statistics, it can be concluded that If Mosul Dam fails, then the catastrophe which follows is by far beyond anything, which had been experienced before or can be imagined to happen in the future. 


\section{Possible Solutions?}

Since the start of the seepage and other problems, solutions were discussed to solve them by the International Board of Experts (IBOE) which had been appointed by the Ministry of Irrigation at that time to follow the designs and the construction of the dam. The IBOE had number of meetings with the designers and contractors discussing the problems at the dam site. Many reports and studies had been also prepared by other consultants and experts who were invited by the Contractors or the Board and even by the Owner were also discussed during these meetings. Grouting problems and type of grout mixtures were among those. Recommendations to use silica gel in the grouting of the left bank curtain in order to reduce seepage appearing in the left bank and very high takes of cement grouts and the use of sand gravel mixes in a number of zones were also considered (see [47] [48]). All studies concluded that the dissolution of rocks that had occurred since impounding was substantial, but not so great as to preclude a successful completion.

Several alternatives were suggested. These were:

a) Precipitation of insoluble materials (such as sodium chloride) from ground seepage water to fill seepage paths. This was rejected since the precipitant volume will not be enough to fill seepage paths of various sizes and that the injected fluid may flow in an unpredicted manner by varying seepage flows.

b) Protecting gypsum or anhydrite surfaces against dissolution by sealing gypsum/anhydrite surfaces. This can be achieved either by maintaining a saturated or super saturated solution with $\mathrm{SO}_{4}$ against the rock surfaces, which requires a continuous supply of solution to seepage water probably from an upstream gypsum blanket. This was also rejected due to large quantities of removed gypsum daily from the foundation and the uncertainty of directions taken by seepage flow path. The other alternative was to provide a chemical solution, which react with $\mathrm{CaSO}_{4}$ to form a highly insoluble coating. This suggests the use of calcium oxalate, but the problem facing this solution is the tenacity and durability of such a coating against further seepage and the uncertainty and difficulties of judging the performance with time. In addition, this material has the toxic effects of oxalate to animals and humans, and the large volumes required to be released into ground water.

c) Use of barriers: This can be achieved by:

i) Blanketing: Blanketing the upstream side of the dam and reservoir (Figure 15). This is normally done by drawing down the reservoir, and to avoid this, dropping the lining materials (bentonite pellets) through pipes lowered into the bottom of the pond then sand would be placed on top to hold the clay in place against any disturbances. This method has not been used in ponds and not in large reservoirs before.

ii) Positive cutoff: A cutoff wall is to be constructed as shown in (Figure 16). This procedure is very risky to be executed now on Mosul Dam. The risk involves the great depth of the cutoff wall, hardness of pervious strata, presence of 


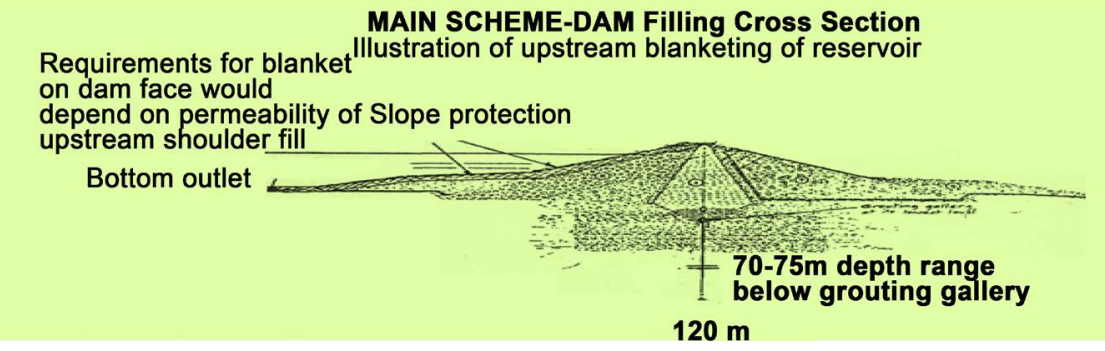

Figure 15. Illustration of upstream blanketing arrangement.

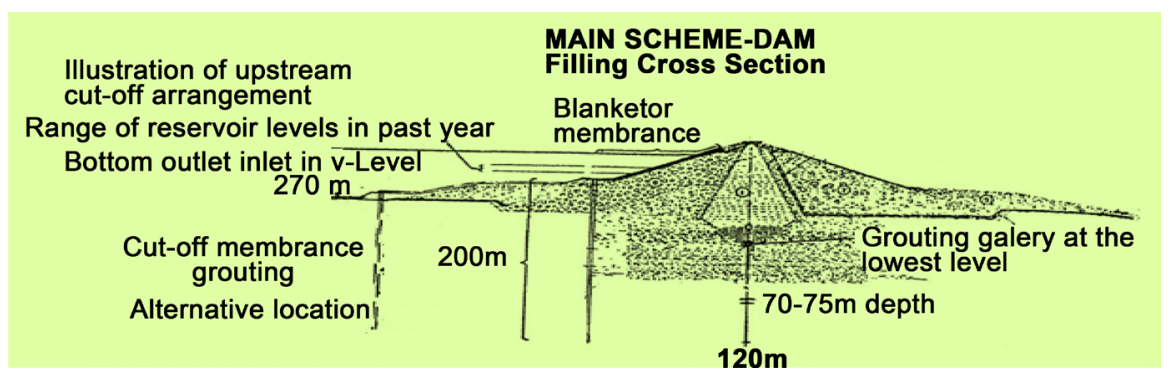

Figure 16. Illustration of upstream cut-off arrangement.

cavities and voids in the foundation, in addition to maintaining the verticality of the diaphragm panels at these unprecedented depths. The Board; however, judged this solution undesirable due to the required lowering of the reservoir level, which could extend 2 - 3 years in addition to the very high cost.

iii) Construction of a new curtain: This is to be done as a direct reinforcement to the existing curtain; this assumes that it could be done in a better geological location in the upstream of the dam in order to provide improvement. The geological conditions are not different upstream the dam, and the construction require the drawing down of the reservoir so such proposal had no value.

The Ministry of Irrigation asked an expert (Mr. Mariotti) to further discuss the problem of the curtain and give suggestions. His report was submitted to the International Board of Experts [49] and the following proposals were given:

a) In the context of strengthening the grout curtain in the problem areas where massive grouting had to be repeated, widening the curtain was recommended. Additional rows of boreholes ought to be drilled consisting of one row upstream of the present curtain and slightly inclined towards the upstream, another row in the downstream of the present curtain and inclined towards downstream, and finally a central vertical row in between. The central row was to be grouted first followed by the upstream row and then the downstream. Finally, the central row would be re-drilled and fine grouting to be performed using silica gel. The Board did not object to this proposal as machinery and grouting capacity were available.

b) The second solution was to construct a tunnel the length of the chalky series from which grouting would be performed. The Board thought that such work was very specialized and would need expert studies to check its feasibility.

c) The third solution was to construct a series of tunnels and galleries to re- 
place risky material. This alternative received the same comments as in (b) above.

d) The fourth alternative was to construct a diaphragm wall from the upstream berm, with a sloping concrete facing from the top of the diaphragm to the top of the dam (Figure 17). Or even to remove part of the top of the dam and install the diaphragm from the top through the core in a location upstream of the gallery. This arrangement was attributed to the unavailability of machines that could cut to the desired level. In a later update, the removal of the dam top was thought unnecessary due to new development in diaphragm machines. This suggestion was disregarded due to technical and economic factors.

All the discussed alternatives were not practical, and some of them were even not feasible. Therefore, it was decided to continue the works on the present curtain by improving the mixes and injection procedure to combat large take areas, sealing large pipes and channels, providing a new array of piezometers taping the known solution areas especially the contact between the pervious limestone and gypsum GB0 layers to monitor the efficiency and the long term performance of the curtain in these soluble layers where windows were most likely would develop.

To take some protective measures due to the possible failure of Mosul Dam, to secure the safety of the downstream area and its' population the Ministry of Irrigation decided to construct Badush Dam in 1988. The design and construction of Badush Dam were initiated in 1988 using fast track method to complete the dam within four years. It is located on the Tigris River, approximately $40 \mathrm{~km}$ downstream from Mosul Dam site and approximately $15 \mathrm{~km}$ upstream of Mosul city (Figure 18). Other functions of the dam were power generation using water discharged by Mosul Dam and by the regulating scheme power plants. The work

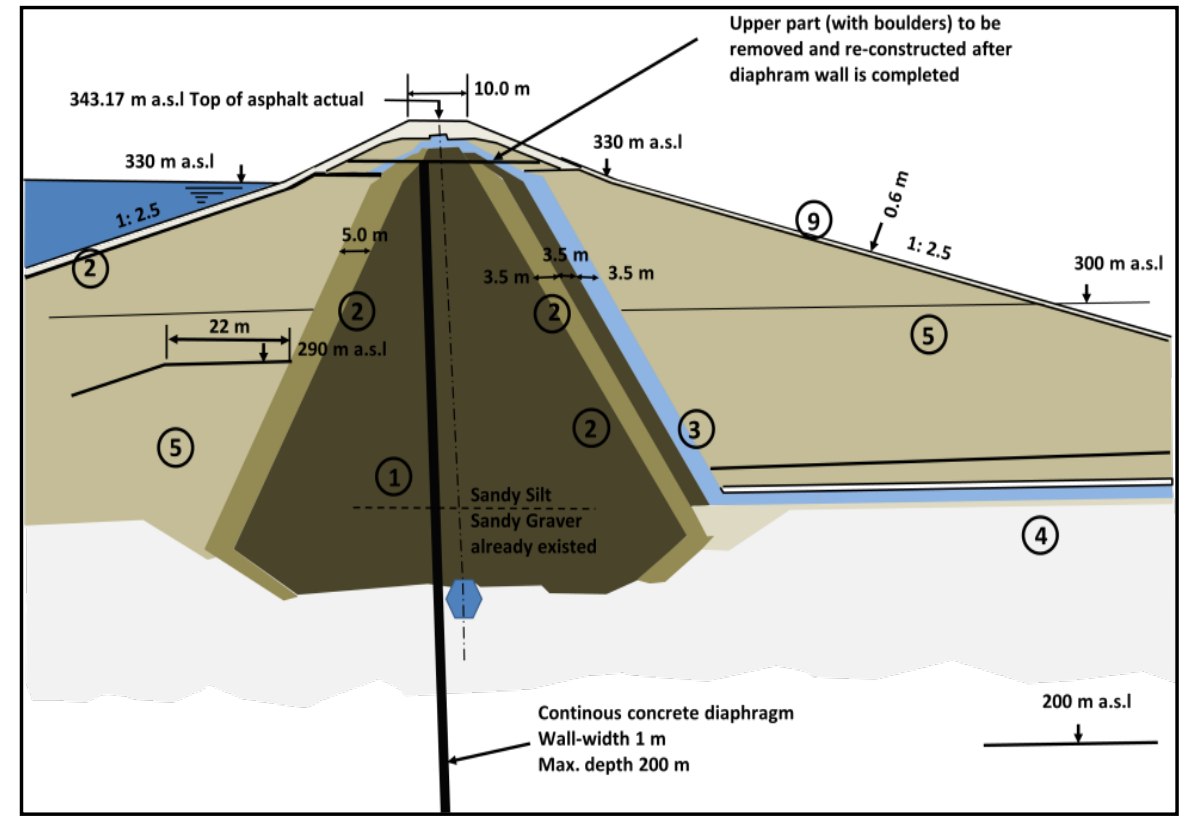

Figure 17. Proposed Diaphragm driven from the dam crest. 


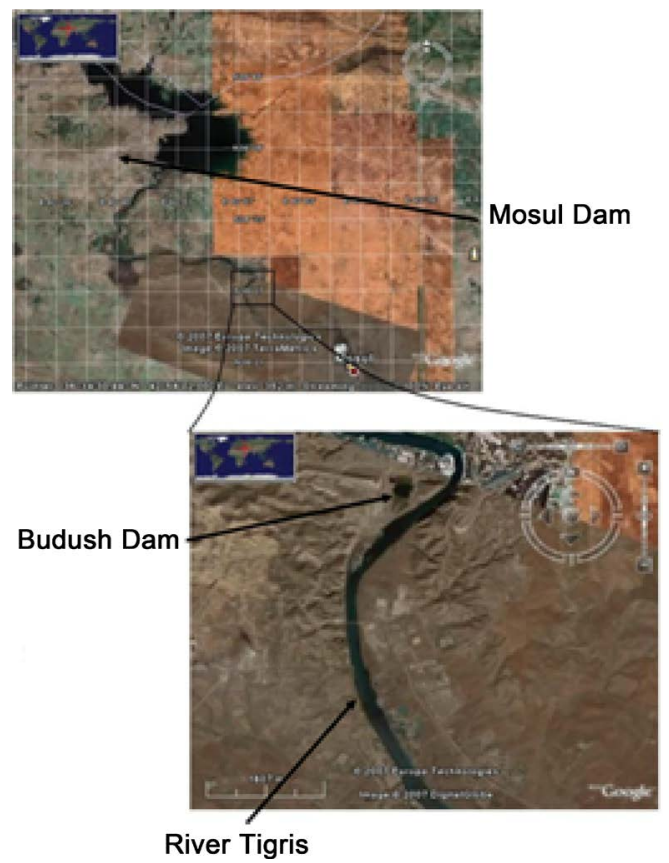

Figure 18. Badush Dam location in relation to Mosul Dam [50].

on this dam was halted in 1991 due to UN sanctions on Iraq.

\section{Conclusions and Recommendations}

Mosul Dam is suffering from the seepage problem under the foundation of the dam since the start of its impounding in 1986. Various works were done to overcome the problem, but it seems that the dam is showing more and more signs of weakness. In view of all the published work and meetings, it is well understood that the geology of the dam site is very complicated, and it suffers from severe problems due to the presence of badly jointed and cavernous soluble gypsum/anhydrite layers, gypsum breccias layers, weathered and jointed limestone and soft marls. The consultants had underestimated these problems where impounding have increased the solubility of the rocks within the vicinity of the dam and enhanced the formation of sinkholes. Despite all the intensive maintenance work the dissolution of gypsum continued and the gypsum breccias layers were very much resistant to grouting at the deep grout curtain zones. Furthermore, it is evident from the work done that grouting can only be a temporary solution and cannot stop permanently the dissolution of gypsum. In addition, it is causing weakening of the rocks by the re-grouting process; it cannot stop the progressive formation of sinkholes and; moreover, it is giving a false sense of security.

Looking at the reports, papers and discussions of researchers and experts, it is believed that the following points are to be considered:

- Keeping the reservoir water level as low as possible for such a period that might be necessary subject to updated risk analysis.

- It is very important to continue grouting operations and to evaluate the ex- 
isting monitoring program and upgrade the system with new available instrumentation to pin point the most critical locations to be grouted.

- Providing possible early warning system for changing conditions that may indicate where and when a failure mechanism is developing.

- Bathymetric survey should be conducted to determine the points of excessive leakage from the reservoir and to detect any sinkhole, spring and seeps within the upstream area in the reservoir close to the dam.

- Emergency Action plan should be developed and implemented, and the public should be aware of such a plan.

- A new panel of experts is to be established to meet every three months to review the status of the grouting program and any new development.

- Since grouting is not the final solution for the problem, other alternatives are to be carefully studied, and a decision should be taken to solve this problem. These solutions may require including the construction of a diaphragm in Mosul Dam, completion of Badush Dam or a hybrid solution of both.

\section{References}

[1] Iraqi Ministry of Water Resources (2012) Water Resources, Mosul Dam. https://www.mowr.gov.iq/en

[2] Al-Ansari, N.A., Barazanji, A., Al-Jabari, M. and Gayara, A. (1984) Geological Investigation of Mosul Dam Site. The Ministry of Irrigation, $41 \mathrm{p}$.

[3] Sissakian, V.K. (1978) Report on the Geological Mapping of Tuz Khurmatu-KifriKalar Area. Iraq Geological Survey Library Report No. 902.

[4] Sissakian, V.K. and Al-Mousawi, H.A. (2007) Karstification and Related Problems, Examples from Iraq. Iraqi Bulletin of Geology and Mining, 3, 1-12.

[5] IVO (Imatran Voima Osakeyhtio) (1969) Consulting Engineers, Finland, Geologic Map of Mosul Dam. Ministry of Agrarian Reform.

[6] Al-Sinjari, M.A. (2007) Characterization and Classification of Some Vertisols West of Duhok Governorate. PhD Thesis, University of Mosul.

[7] Sissakian, V.K., Al-Ansari, N. and Knutson, S. (2014) Karstification Problems in Mosul Dam and Its Assessment. North Iraq. Engineering, 6, 84-92.

https://doi.org/10.4236/eng.2014.62012

[8] Adamo, N., Al-Ansari, N.A., Issa, I.E., Sissakian, V. and Knutsson, S. (2015) Mystery of Mosul Dam the Most Dangerous Dam in the World: Problems Encountered during and after Impounding the Reservoir. Journal of Earth Sciences and Geotechnical Engineering, 5, 47-58.

[9] Adamo, N., Al-Ansari, N.A., Issa, I.E., Sissakian, V. and Knutsson, S. (2015) Mystery of Mosul Dam the Most Dangerous Dam in the World: Foundation Treatment during Construction. Journal of Earth Sciences and Geotechnical Engineering, 5, 59-69.

[10] Adamo, N., Al-Ansari, N.A., Issa, I.E., Sissakian, V. and Knutsson, S. (2015) Mystery of Mosul Dam the Most Dangerous Dam in the World: Maintenance Grouting. Journal of Earth Sciences and Geotechnical Engineering, 5, 71-77.

[11] Adamo, N., Al-Ansari, N.A., Issa, I.E., Sissakian, V. and Knutsson, S. (2015) Mystery of Mosul Dam the Most Dangerous Dam in the World: Experts Proposals and Ideas on Mosul Dam. Journal of Earth Sciences and Geotechnical Engineering, 5, 
79-93.

[12] Al-Ansari, N.A., Issa, I.E., Sissakian, V., Adamo, N. and Knutsson, S. (2015) Mystery of Mosul Dam the Most Dangerous Dam in the World: The Project. Journal of Earth Sciences and Geotechnical Engineering, 5, 15-31.

[13] Al-Ansari, N.A., Adamo, N., Issa, I.E., Sissakian, V. and Knutsson, S. (2015) Mystery of Mosul Dam the Most Dangerous Dam in the World: Karstification and Sinkholes. Journal of Earth Sciences and Geotechnical Engineering, 5, 33-45.

[14] Al-Ansari, N.A., Adamo, N., Issa, I.E., Sissakian, V. and Knutsson, S. (2015) Mystery of Mosul Dam the Most Dangerous Dam in the World: Dam Failure and Its Consequences. Journal of Earth Sciences and Geotechnical Engineering, 5, 91-111.

[15] Al-Ansari, N.A. (2015) Geological and Engineering Investigations of the Most Dangerous Dam in the World. SCIENPRESS, London.

[16] Sissakian, V., Al-Ansari, N.A., Issa, I.E., Adamo, N. and Knutsson, S. (2015) Mystery of Mosul Dam the Most Dangerous Dam in the World: General Geology. Journal of Earth Sciences and Geotechnical Engineering, 5, 1-13.

[17] Adamo, N. and Al-Ansari, N.A. (2016) Mosul Dam Full Story: Safety Evaluation of Mosul Dam. Journal of Earth Sciences and Geotechnical Engineering, 6, 185-212.

[18] Adamo, N. and Al-Ansari, N.A. (2016) Mosul Dam Full Story: Engineering Problems. Journal of Earth Sciences and Geotechnical Engineering, 6, 213-244.

[19] Adamo, N. and Al-Ansari, N.A. (2016) Mosul Dam Full Story: What if the Dam Fails? Journal of Earth Sciences and Geotechnical Engineering, 6, 245-269.

[20] Wakeley, L.D., Kelley, J.R., Talbot, C.A., Pearson, M.L. and Broadfoot, S.W. (2007) Geologic Conceptual Model of Mosul Dam. U.S. Army Engineer Research and Development Center, $61 \mathrm{p}$.

[21] Sissakian, V.K., Abdul Ahad, A.D. and Hamid, A.T. (2011) Geological Hazards in Iraq, Classification and Geographical Distribution. Iraqi Bulletin of Geology and Mining, 7, 1-28.

[22] Kelly, J., Wakeley, L.D., Broadfoot, S.W., Pearson, M.L., McGill, T.E., Jorgeson, J.D., Talbot, C.A. and McGrath, C.J. (2007) Geologic Setting of Mosul Dam and Its Engineering Implications. Final Report, U.S. Army Engineer District, Gulf Region, Baghdad.

[23] Swiss Consultants (1979) Mosul Dam Project-Planning Report, Vol. 1, State Organization of Dams, Republic of Iraq, Ministry of Irrigation.

[24] Black and Veatch (2004) Mosul Dam Assessment, Review of 1984 Dambreak and Floadwave Study for Mosul Dam, Mosul Dam Library, Iraq.

[25] Mark and Wheeler (2004) Mosul Dam Assessment, Task Order No. 8, Report on Site Visit, Mosul Dam Library, 3-7 September, 2004.

[26] Sissakian, V.K. and Ibrahim, F.A. (2004) Geological Hazards Map of Mosul Quadrangle, Scale 1:250000. Iraq Geological Survey Library Report No. 2860.

[27] Washington Group International (2005) Inter-Office Correspondence. Mosul Dam Library.

[28] Hijab, S.R. and Al-Jabbar, M.A. (2006) Geophysical Investigation on Mosul Dam Area, Stage One, Emergency Microgravity Survey. Iraq Geological Survey Library, Internal Report.

[29] Issa, E.I., Al-Ansari, N.A. and Knutsson, S. (2013) Changes in Bed Morphology of Mosul Dam Reservoir. Journal of Advanced Science and Engineering Research, 3, 86-95. 
[30] Swiss Consultant (1984) Mosul Dam Project Hydrological Study on Right Bank Report. State Organization of Dams, Republic of Iraq, Ministry of Irrigation, June 1984.

[31] Deere, D.U. and Deere, D.W. (1989) Rock Quality Designation (RQD) after Twenty Years Contract Report GL-89-1. U.S. Army Engineer Waterways Experiment Station, Vicksburg.

[32] Al-Abayachi, S. (2016) Report on Mosul Dam, Iraqi House of Representatives. Agriculture, Water, and Marshes Sub-Committee. https://drive.google.com/file/d/0Byn0PFg9wZ5FNHNQUmxLb0JzenM/view

[33] Coffman, R. (2014) Mosul Dam Could Fail if ISIS Doesn't Continue Grouting Operations. Expert Says, University of Arkansas, Fayetteville, Article ID: 621536.

[34] Cetinic, F. (2016) Satellite Based Information to Support Health Analysis of Mosul Dam. International Workshop on Mosul Dam, Stockholm, 24-25 May 2016.

[35] MaCleanathan, J.T. (2009) Update for Screening Portfolio Risk Analysis for U.S Army Corps of Engineers Dams. Risks and Reliability Directorate USACE.

[36] U.S. Department of the Interior Bureau of Reclamation (2014) Interim RCEM (Reclamation Consequence Estimating Methodology). Guidelines for Estimating Life Loss for Dam Safety Risk Analysis, February 2014.

[37] Milillo, P., Bürgmann, R., Lundgren, P., Salzer, J., Perissin, D., Fielding, E., Biondi, F. and Milillo, G. (2016) Space Geodetic Monitoring of Engineered Structures: The Ongoing Destabilization of the Mosul Dam, Iraq. Scientific Reports, 6, Article No. 37408. http://www.nature.com/articles/srep37408 https://doi.org/10.1038/srep37408

[38] Swiss Consultants (1984) Security Measures II, Addendum 3-Flood Wave Studies, Task 2 Mosul Flood Wave, Confidential Report for the Ministry of Irrigation, State Organization of Dams, V. 1 (Summary), V. 2 (The Model and Model Calibration), V. 3 (Calculation of Mosul Flood Wave).

[39] Swiss Consultants (1984) Security Measures II, Addendum 3-Flood Wave Studies, Task 2 Mosul Flood Wave, Confidential Report for the Ministry of Irrigation, State Organization of Dams, V. 1 (Summary), V. 2 (The Model and Model Calibration), 3 (Calculation of Mosul Flood Wave).

[40] Swiss Consultants Consortum (1984) Mosul Dam Flood Wave. Summary, Vol. 1.

[41] Swiss Consultants Consortum (1984) Mosul Dam Flood Wave. Model Calibration, Vol. 2.

[42] Swiss Consultants Consortum (1984) Mosul Dam Flood Wave. Calculation, Vol. 3.

[43] Al-Taiee, T.M. and Rasheed, M.M. (2009) Simulation Tigris River Flood Wave in Mosul City Due to hypothetical Mosul Dam. 13th International Water Technology Conference, Hurghada.

[44] Mahmud, M.I., Al Azawi, A.O., Abdul Majeed, A.T. and Khalil, T.W. (2015) Mosul Dam Break Scenario and Its Effects on the Areas along the River down to Baghdad. Ministry of Higher Education and Scientific Research, Center for Catastrophes Data Management and Space Archives, Baghdad. (In Arabic)

[45] Annunziato, A., Andredakis, I. and Probst, P. (2016) Impact of Flood by a Possible Failure of the Mosul Dam. Version 2, Joint Research Centre JRC Technical Reports, EU Commission.

http://publications.jrc.ec.europa.eu/repository/bitstream/JRC101555/lbna27923enn. pdf

[46] Franchello, F. and Krausmann, E. (2008) HyFlux2: A Numerical Model for the Im- 
pact Assessment of Severe Inundation Scenario to Chemical Facilities and Downstream Environment. EUR 23354 EN-2008.

http://www.google.se/url?sa=t\&rct=j\&q=\&esrc=s\&source=web\&cd=2\&ved=0ahUK EwiMrcDK4tfRAhWC1iwKHf9MA3wQFggeMAE\&url=http\%3A\%2F\%2Fportal.gd acs.org\%2Fabout\%2FPublications\%2FItemID\%2F205\%2FModID\%2F662\&usg=AF QjCNEG-Mtyu2tSVcrmS_-6nWjrvmfAgw\&bvm=bv.144224172,d.bGg

[47] Luga, R. (1986) Report on Visit in February 1986 Concerning Grouting Works. GEOCONSEIL, Ministry of Irrigation, Baghdad.

[48] Binnie and Partners (1987) Mosul Dam Foundation Cut-Off. Report, Ministry of Irrigation, Baghdad.

[49] IBOE (1989) International Board of Experts. Interim Meeting Report, Ministry of Irrigation, Baghdad, Iraq.

[50] Al-Adily, A., Khasaf, S. and Ajaj, A. (2014) Hydrological Impacts of Iraqi Badush Dam on Ground Water. International Water Technology Journal, 4, 90-106. 